\title{
PENYELESAIAN SENGKETA BATAS PENGUASAAN TANAH DI KAWASAN HUTAN ANTARA PT. SIDOSARI MULTIFARM DENGAN PERHUTANI KPH BALAPULANG
}

\author{
Michelle Tiffani D.N., Sukirno, Irma Cahyaningtyas \\ Program Studi Magister Kenotariatan \\ Fakultas Hukum, Universitas Diponegoro \\ Email : michelletiffani999@gmail.com
}

\begin{abstract}
Uncertainty in the area of various parties concerned with forest areas. At the field level, boundaries in the form of forest boundaries are also often unclear. One of the problems regarding the conflict is the boundaries of the forest area that occurred in the village of Buara Ketanggungan Brebes, which began when in 2016 PT. Sidosari Multifarm will establish a chicken farm. Problem formulation in this research are the factors that cause disputes and how to over land tenure in the forest area between PT. Sidosari Multifarm with Perhutani KPH Balapulang resolve land tenure disputes in the forest area between PT. Sidosari Multifarm with Perhutani KPH Balapulang. The research metode used is empirical judicial. The results showed: (1) the factors causing the dispute between PT. Sidosari Multifarm and Perhutani KPH Balapulang due to differences in proof of ownership rights, differences in measurement results, and proof of ownership owned by both parties not yet certified; (2) the settlement efforts between the two parties were unsuccessful because of differences in principles regarding the origin of land ownership also made the two parties maintain their respective opinions.
\end{abstract}

Keywords: forest area; dispute resolution; grondkaart; letter C

\begin{abstract}
Abstrak
Ketidakpastian areal berbagai pihak yang berkepentingan dengan kawasan hutan. Salah satunya mengenai konflik adalah mengenai tata batas pada kawasan hutan yang terjadi di desa Buara Ketanggungan Brebes yang bermula ketika pada tahun 2016 PT. Sidosari Multifarm akan mendirikan peternakan ayam. Rumusan Masalah dalam penelitian ini adalah faktor-faktor yang menjadi penyebab dan cara penyelesaian sengketa batas penguasaan tanah di kawasan hutan antara PT. Sidosari Multifarm dengan Perhutani KPH Balapulang. Metode penelitian yang digunakan adalah yuridis empiris. Hasil penelitian menunjukkan: (1) faktor-faktor terjadinya sengketa antara PT. Sidosari Multifarm dengan Perhutani KPH Balapulang karena adanya perbedaan bukti kepemilikan hak, perbedaan hasil ukur, dan alas bukti kepemilikan yang dimiliki kedua pihak belum bersertifikat; (2) upaya penyelesaian antara kedua belah pihak tidak berhasil karena adanya perbedaan prinsip mengenai asal mula kepemilikan tanah juga menjadikan kedua pihak mempertahankan pendapat masing-masing.
\end{abstract}

Kata kunci : kawasan hutan; penyelesaian sengketa; peta belanda; letter C

\section{A. Pendahuluan}

Ketidakpastian areal kawasan hutan merupakan salah satu yang menghambat efektivitas tata kelola hutan di Indonesia. Dari seluruh kawasan hutan seluas 130 juta hektar maka areal yang telah selesai ditatabatas sekitar 12 persen (14,2 juta hektar). Ketidakpastian ini memicu 
munculnya konflik tenurial (lahan) dengan berbagai pihak yang berkepentingan dengan kawasan hutan. Padahal setidak-tidaknya terdapat 50 juta orang yang bermukim disekitar kawasan hutan dengan lebih dari 33 ribu desa yang berbatasan dengan kawasan hutan (Nurjaya, 2017).

Persoalan ketidakpastian tata batas hutan ini tidak hanya menimpa masyarakat adat ataupun masyarakat lokal yang berdiam dan memanfaatkan lahan dan sumber daya di dalam kawasan hutan, tetapi juga institusi yang memiliki izin usaha kehutanan dan pemerintah. Di tingkat lapangan batas yang berupa patok batas hutan juga seringkali tidak jelas sehingga sulit diverifikasi dalam pembuatan berita acara.

Untuk memberikan kepastian hukum atas kawasan hutan, maka diperlukan proses pengukuhan kawasan hutan, dimana seluruh proses yang harus dilakukan adalah penunjukan, penetapan batas, pemetaan dan penetapan kawasan hutan. Proses ini semua adalah untuk menuju suatu kawasan hutan yang "legal dan legitimate" (Safitri, 2018).

Menurut Benhard Limbong, konflik agraria adalah proses interaksi antara dua (atau lebih) atau kelompok yang masing-masing memperjuangkan kepentingannya atas objek yang sama, yaitu tanah dan benda-benda lain yang berkaitan dengan tanah, seperti air, tanaman, tambang, juga udara yang berada di atas tanah yang bersangkutan. Sementara itu akar konflik pertanahan dalam garis besarnya dapat ditimbulkan oleh hal-hal sebagai berikut (Limbong, 2012):

1. Konflik kepentingan, yaitu adanya persaingan kepentingan yang terkait dengan kepentingan subtantif, kepentingan prosedural, maupun kepentingan, psikologis,

2. Konflik struktural,yang disebabkan pola perilaku desdruktif, kontrol perilaku sumber daya yang tidak seimbang,

3. Konflik nilai, karena perbedaan kriteria yang dipergunakan mengevaluasi gagasan/perilaku, perbedaan gaya hidup, ideologi atau agama/kepercayaan,

4. Konflik hubungan, yang disebabkan karena emosi yang berlebihan, persepsi yang keliru, komunikasi yang buruk/salah, perilaku yang negatif,

5. Konflik data, yang disebabkan karena informasi yang tidak lengkap, informasi yang keliru, pendapat yang berbeda tentang hal-hal yang relevan, interpretasi data yang berbeda dan perbedaan prosedur penilaian.

Harus dipahami pula, konflik agraria yang berlangsung saat ini adalah konflik data yang melibatkan penduduk setempat berhadapan dengan instrumen negara. Akar konflik pertanahan tersebut diatas merupakan faktor mendasar yang menyebabkan timbulnya konflik pertanahan. Konflik agraria yang terjadi pada umumnya disebabkan oleh kebijakan pemerintah yang seolah-olah memiliki tanah tersebut dengan dalih bahwa tanah tersebut adalah tanah negara (Limbong, 2012). Salah satu permasalahan mengenai konflik data adalah mengenai tata batas pada kawasan hutan yang terjadi di desa Buara Ketanggungan Brebes. 
Konflik merupakan situasi atau kondisi adanya pertentangan atau ketidaksesuaian antara para pihak yang akan dan sedang mengerjakan kerjasama (Sarjita, 2005). Konflik tidak akan terjadi apabila konflik tersebut dipendam oleh pihak yang merasa dirugikan. Konflik tersebut akan menjadi sengketa jika pihak yang merasa dirugikan menyatakan ketidakpuasan maka dengan demikian, sengketa merupakan kelanjutan dari konflik atau sebuah konflik akan menjadi sengketa apabila tidak diselesaikan (Sitorus, 2004).

Terjadinya sengketa dalam hukum pertanahan disebabkan karena perbedaan pendapat mengenai keabsahan suatu hak, pemberian hak atas tanah, pendaftaran hak atas tanah termasuk peralihan dan penerbitan tanda bukti hak atas tanah (Murad, 2007). Sengketa ini menunjukan bahwa terjadinya sengketa disebabkan karena perbedaan pandangan dalam interaksi masyarakat dengan tanah.

Sengketa tanah kawasan hutan terjadi karena tata batas/akses, perambahan hutan, pencurian kayu, perusakan lingkungan dan alih fungsi kawasan hutan tata batas atau akses merupakan masalah yang timbul sejak dulu. Tumpang tindih antara kawasan lindung dengan HPH (Hak Pengusahaan Hutan) dan lahan pertanian masyarakat menjadi masalah serius, sehingga mengakibatkan ketidakpastian apakah batas yang diketahui oleh masyarakat atau yang dibuat oleh pemerintah yang menjadi dasar sebagai batas kawasan hutan (Wulan, 2016). Masalah perambahan dan pencurian kayu diakibatkan oleh cara pandang tata batas kawasan hutan. Penyebab lain terjadinya konflik tanah dalam kawasan hutan disebabkan oleh konflik yang berlatar ketidakadaan akses masyarakat sekitar hutan untuk bisa mengelola hutan (konflik akses) dan konflik hutan yang berbasiskan (hak atas) tanah. Konflik akses terjadi, ketika seluruh hutan dikuasai oleh Perhutani meskipun masuk dalam kawasan desa. Hal ini berdampak masyarakat disekitar hutan tidak mendapatkan akses untuk mengelola hutan. Konflik hak atas tanah terjadi karena pengambilalihan tanah-tanah hasil membuka hutan atau tanah-tanah garapan masyarakat oleh Perhutani (Roqhmad, 2017).

Salah satu permasalahan mengenai konflik data adalah mengenai tata batas pada kawasan hutan yang terjadi di desa Buara Ketanggungan Brebes yang bermula ketika PT. Sidosari Multifarm akan mendirikan peternakan ayam. Dari keseluruhan alas hak dari penjual, sebagian besar hanya berupa Letter C. Setelah dilakukan pengukuran pada tahun 2017 ternyata ditemukan banyak Letter $\mathrm{C}$ yang luas tanahnya tidak sesuai dengan hasil pengukuran.

Setelah proses pengukuran dan pelunasan pembayaran tanah selesai, ada sekitar 5 hektar yang mana tanah tersebut adalah milik Perhutani dan dari pihak BPN Kanwil Jateng mengatakan bahwa akan menunda penerbitan sertifikat tersebut. Permasalahan hukum yang 
terjadi pada kasus ini adalah antara tata batas Peta Desa dengan Peta Belanda yang dimiliki Perhutani tidak sesuai satu sama lain.

Dengan demikian jika sengketa batas penguasaan tanah tidak segera dicari pola-pola penyelesaiannya, maka sengketa batas penguasaan tanah antara PT. Sidosari Multifarm dengan Perhutani akan tetap berlanjut dan akan membawa akibat dan preseden yang buruk terutama akan kepastian hukum terhadap hak atas tanah. Oleh karena itu perlu mencari cara penyelesaian terbaik untuk penyelesaian sengketa tersebut.

Berdasarkan latar belakang yang tersebut di atas maka dapat dirumuskan permasalahan yaitu faktor-faktor apakah yang menjadi penyebab sengketa batas penguasaan tanah di kawasan hutan antara PT. Sidosari Multifarm dengan Perhutani KPH Balapulang serta cara penyelesaian sengketa batas penguasaan tanah di kawasan hutan antara PT. Sidosari Multifarm dengan Perhutani KPH Balapulang.

Beberapa artikel yang ada sebelumnya diantaranya, artikel mengenai mengenai dasar hukum penguasaan tanah di blok Gunung Cibuluh KPH Ciamis (Manshur, 2015); kemudian artikel lainnya dengan permasalahan mengenai dasar penunjukkan kawasan lindung balang pesoang (Febrina, 2017). Pada artikel ini akan membahas mengenai faktor-faktor terjadinya sengketa antara PT. Sidosari Multifarm dengan Perhutani KPH Balapulang dan upaya penyelesaian antara kedua belah pihak mengenai asal mula kepemilikan tanah.

\section{B. Metode Penelitian}

Metode penelitian yang digunakan dalam artikel ini adalah metode pendekatan yuridis empiris, Pendekatan yuridis adalah mempelajari aturan-aturan yang ada dengan masalah yang diteliti. Sementara itu pendekatan empiris adalah memberikan kerangka pembuktian atau kerangka pengujian untuk memastikan suatu kebenaran (Soemitro, 1997). Dengan demikian pendekatan yuridis empiris adalah sebuah metode penelitian hukum yang berupaya untuk melihat hukum dalam artian yang nyata atau dapat dikatakan melihat, meneliti, bagaimana bekerjanya hukum di masyarakat (Soemitro, 1997). Artikel ini mendasarkan pada fakta-fakta, peraturan perundang-undangan dan teori-teori yang berkaitan dengan sengketa batas penguasaan tanah antara PT. Sidosari Multifarm dengan Perhutani KPH Balapulang. Sehingga bisa diperjelas bahwa penelitian ini menggunakan metode yuridis empiris.

\section{Hasil Dan Pembahasan}

Sengketa batas penguasaan antara PT. Sidosari Multifarm dengan Perhutani Balapulang telah melalui tiga tahap, yaitu tahap keluhan, tahap konflik, dan tahap sengketa. Model-model 
penyelesaian sengketa yang lazim digunakan menurut Nader dan Todd adalah arbitrasi, negosiasi, mediasi, judikasi, paksaan dan penghindaran.

Salah satu dari alternatif penyelesaian sengketa yang sudah lama dikenal dan banyak digunakan adalah negosiasi. Negosiasi adalah fact of life atau keseharian. Setiap orang melakukan negosiasi untuk mendapatkan apa yang diinginkan dari orang lain (Margono, 2004).

Negosiasi berasal dari bahasa Inggris, negotiation yang artinya perundingan. Dalam bahasa sehari-hari, negosiasi sepadan dengan istilah berunding, bermusyawarah atau bermufaka (Sutiyoso, 2006).

Musyawarah mengedepankan nilai kebersamaan dan kekeluargaan dalam menyelesaikan setiap permasalahan, sehingga setiap hasil keputusan musyawarah dapat merangkul semua pendapat dan tidak mementingkan kepentingan sendiri. Dalam perkembangannya, musyawarah tidak lagi digunakan untuk kepentingan bermasyarakat dan bernegara, namun juga diterapkan dalam penyelesaian sengketa pertanahan. Musyawarah dilakukan oleh dua atau lebih pihak yang bersengketa dengan tujuan mendapatkan penyelesaian yang bisa merangkul semua pihak.

Dalam sengketa batas penguasaan antara PT. Sidosari Multifarm dengan Perhutani KPH Balapulang, model penyelesaian yang ditempuh adalah negosiasi. Dari hasil negosiasi antara PT. Sidosari Multifarm dan Perhutani KPH Balapulang memberikan hasil sebagai berikut:

\section{Bulan Desember 2018}

PT. Sidosari Multifarm menunjukkan peta hasil ukur yang dilakukan oleh petugas ukur dari Kantor Pertanahan Kabupaten Brebes sedangkan KPH Balapulang menunjukkan Peta Belanda sebagai bukti penguasaan. Pihak PT. Sidosari Multifarm mengatakan bahwa alat ukur dari Kantor Pertanahan sudah modern dan menganggap bahwa tidak terjadi kesalahan ukur karena pada saat pengukuran, didampingi oleh pemilik, penujuk batas dari pamong desa dan mantri hutan mengetahui jika ada pengukuran tanah di sekitar kawasaan hutan milik Perhutani KPH Balapulang. Namun pihak KPH Balapulang menganggap bahwa pengukuran tersebut melewati tapal batas yang telah dipasang oleh pihak Perhutani KPH Balapulang. Pada negosiasi pertama ini, tidak ditemukan kesepakatan karena masing-masing pihak tetap mempertahankan alat bukti yang dimiliki.

2. Bulan Juni 2019

Setelah dilakukan mediasi pertama, para pihak membahas mengenai solusi penyelesaian sengketa penguasaan tanah. PT. Sidosari Multifarm merasa keberatan akibat luas tanah yang berkurang cukup banyak dan keberatan jika harus melepas tanah yang sudah dibeli, pihak PT. Sidosari Multifarm menjelaskan bahwa tanah yang di beli dari warga memang sudah 
diwariskan turun-temurun dan tidak pernah ada klaim dari pihak manapun. Disamping itu, PT. Sidosari Multifarm sudah menggarap sebagian tanah yang telah dibeli dan karena hal tersebut, biaya yang dikeluarkan oleh pihak PT. Sidosari Multifarm sudah sangat banyak. Dari keterangan yang diberikan oleh pihak PT. Sidosari Multifarm, pihak Perhutani KPH Balapulang tidak memperdulikan hal tersebut dan masih bertahan dengan bukti kepemilikan yang dimiliki yaitu Peta Belanda.

3. Bulan Desember 2019

Dari pertemuan sebelumnya, kemudian para pihak bertemu kembali untuk mengutarakan keinginan masing-masing dengan penawaran solusi yang dimiliki oleh masing-masing pihak. Dari pihak Perhutani KPH Balapulang mengatakan bahwa jika PT. Sidosari Multifarm tetap ingin menguasai tanah yang telah melanggar batas, PT. Sidosari Multifarm harus mengganti tanah seluas 2 (dua) kali lipat dari tanah yang telah dilanggar oleh PT. Sidosari Multifarm, atau biasa dikenal dengan sebutan "tukar guling", tetapi pihak PT. Sidosari Multifarm tentu keberatan dengan penawaran tersebut. Kemudian dari pihak PT. Sidosari meminta bukti kepemilikan lain yang dimilik Perhutani KPH Balapulang selain Peta Belanda, karena pihak PT. Sidosari Multifarm menganggap bukti kepemilikan tersebut sudah tidak relevan dengan adanya reformasi Agraria yang mewajibkan pensertifikatan tanah pada setiap penguasaan/kepemilikan tanah. Pihak Perhutani KPH Balapulang mengatakan bahwa hal tersebut tidak diperlukan karena penguasaan tanah Perhutani telah diatur oleh UU Kehutanan. Dari hasil negosiasi ini, tidak ditemukan kesepakatan hingga saat ini.

Perbedaan sudut pandang penafsiran dari kedua pihak, menurut artikel ini disebabkan oleh karena masing-masing pihak berpijak atau mengacu pada ketentuan dan dasar hukum yang berbeda. Di satu sisi, dasar hukum yang digunakan adalah UUPA dan peraturan pelaksanaannya, sedangkan di sisi Perhutani didasarkan kepada ketentuan Undang-Undang Kehutanan beserta peraturan pelaksanaannya.

Menurut artikel ini, perbedaan pendapat tersebut disebabkan oleh dan merupakan konsekuensi logis dari penerapan Hak Menguasai Negara yang ada pada undang-undang sektoral yang mengatur sumber daya alam, seperti Undang-Undang Nomor 5 Tahun 1960 Tentang Peraturan Dasar Pokok-pokok Agraria, Undang-Undang Nomor 11 Tahun 1967 Tentang Pokok-pokok Pertambangan, Undang-Undang Nomor 23 Tahun 1997 Tentang Lingkungan Hidup, dan Undang-Undang Nomor 41 Tahun 1999 Tentang Kehutanan.

Menurut Benhard Limbong, UUPA adalah induk dari peraturan di bidang sumber agraria lainnya, namun seiring berjalannya waktu telah dibuat peraturan perundang-undangan yang 
berkaitan dengan sumber daya agrarian tapi tidak menempatkan UUPA sebagai undang-undang induknya, bahkan menempatkan UUPA sejajar dengan undang-undang mengenai agrarian lainnya. Struktur hukum pertanahan menjadi tumpang tindih. UUPA yang awalnya merupakan payung hukum bagi kebijakan pertanahan dan kebijakan agraria umumnya di Indonesia, menjadi tidak berfungsi dan bahkan secara substansial terhadap pertentangan dengan diterbitkannya berbagai peraturan sektoral seperti Undang-Undang Nomor 5 Tahun 1967 tentang Pokok-pokok Kehutanan yang diperbarui dengan Undang-Undang Nomor 41 Tahun 1999 Tentang Kehutanan (Limbong, 2012).

Keseluruhan undang-undang tersebut mempunyai posisi yang sama dan menjadikan tanah sebagai objek yang sama. Benturan di lapangan tidak dapat dihindarkan, antara penggunaan dan penafsiran undang-undang yang berbeda oleh pejabat-pejabat pemerintah sektoral yang berbeda-beda terjadi atas konflik penguasaan tanah yang sama. Perbedaan antara undang-undang tersebut di atas tidak hanya dapat memberikan peluang pada perbedaan interpretasi para birokrat, tetapi juga secara substansial undang-undang tersebut tidak integratif (Supriadi, 2012).

Menurut Achmad Sodiki, inti permasalahan adalah pada Hak Menguasai Negara yang diterapkan pada undang-undang sektoral tersebut tidak menunjukkan kesamaan penafsiran tentang isi dan batas-batasnya. Sehingga terkesan adanya tumpang tindih kewenangan. Hal ini menimbulkan ketidakpastian hukum. Lebih lanjut Achmad Sodiki menyatakan, dari sudut pandang yuridis normatif, disamping UUPA telah timbul berbagai undang-undang yang mengakibatkan ketidakpastian hukum, baik yang berupa kepastian dalam hukum dan kepastian karena hukum (Sodiki, 2009).

Mengenai pokok masalah tersebut, Maria S.W. Sumardjono menyatakan bahwa UUPA dimaksudkan untuk mengatur objek materiil bumi, air, ruang angkasa dan kekayaan alam yang terkandung di dalamnya (sumber daya agraria) karena berbagai kendala baru berhasil mengatur sebagian objek materiil, yaitu pertanahan. Bagian yang belum diselesaikan itu, karena kebutuhan pragmatis untuk mengakomodasikan pertumbuhan ekonomi pada tahun 1970-an, telah di oper oleh berbagai peraturan undang-undang sektoral seperti Undang-Undang Nomor 41 Tahun Tentang Pokok-pokok Kehutanan, Undang-Undang Nomor 11 Tahun 2967 Tentang Pertambangan dan Undang-Undang Nomor 11 Tahun 1974 Tentang Pengairan.

Lebih lanjut dikatakan oleh Maria S.W. Sumardjono, bahwa pengkotakan peraturan perundang-undangan dalam bingkai sektoral ini sudah berjalan demikian lama sehingga diamdiam diterima sebagai sebuah kenyataan walau dengan akibat inkonsistensi, tumpang tindih 
antar peraturan perundang-undangan sektoral, serta longgarnya koordinasi di tingkat pusat maupun antara pusat dan daerah, dengan segala dampaknya (Soemardjono, 2017).

Selain perbedaan penafsiran hukum, bisa dipahami bahwa perbedaan hasil ukur atau perbedaan bukti kepemilikan menjadikan kedua pihak mempertahankan pendapat masingmasing dan tidak menemukan kesepakatan.

\section{Simpulan}

Berdasarkan hasil penelitian dapat disimpulkan bahwa faktor-faktor penyebab sengketa penguasaan batas penguasaan tanah antara PT. Sidosari Multifarm dengan Perhutani KPH Balapulang karena: (1) Perbedaan bukti kepemilikan hak. Bukti kepemilikan yang dimiliki PT. Sidosari multifarm berupa kumpulan Letter C dari pemilik sebelumnya. Sedangkan bukti kepemilikan yang dimilik Perhutani KPH Balapulang berupa Peta Belanda yang sudah tidak relevan dengan Reformasi Agraria yang mengharuskan bahwa setiap kepemilikan/penguasaan tanah harus di sertifikatkan; (2) Perbedaan hasil ukur, pengukuran yang dilakukan PT. Sidosari Multifarm oleh Kantor Pertanahan Kabupaten Brebes dianggap lebih modern dibandingkan pengukuran yang dilakukan pada zaman Belanda; (3) Alas bukti kepemilikan yang dimiliki kedua pihak belum bersertifikat. Sedangkan upaya penyelesaian antara kedua belah pihak tidak berhasil karena: (1) Masing-masing pihak mempertahankan bukti kepemilikan tanah yang dimiliki; (2) Adanya perbedaan prinsip mengenai asal mula kepemilikan tanah menjadikan kedua pihak mempertahankan pendapat masing-masing; (3) Penawaran solusi yang diberikan pihak Perhutani KPH Balapulang dianggap memberatkan pihak PT. Sidosari Multifarm sedangkan peraturan atas penawaran dari Perhutani KPH Balapulang memang telah tercantum pada Peraturan Menteri Lingkungan Hidup dan Kawasan Hutan Nomor P.97/MENLHK/SETJEN/KUM.1/11/2018 Tentang Tata Cara Pelepasan Kawasan Hutan yang Dapat Dikonversi. 


\section{DAFTAR PUSTAKA}

\section{BUKU :}

Perlindungan Hukum Pemegang Sertifikat Hak Milik Atas Tanah Pasca Ditetapkannya Sebagai Kawasan Hutan Lindung Di Kabupaten Bulukamba.

Limbong, B. (2012). Hukum Agraria Nasional. Jakarta: Margaretha Pustaka.

Limbong, B. (2012). Jakarta: Margaretha Pustaka.

Manshur, D. S. (2015). Analisis Yuridis Terhadap Penguasaan Tanah Dalam Kawasan Hutan.

Margono, S. (2004). Alternative Dispute Resolution dan Arbitrase: Proses Pelembagaan dan Aspek Hukum. Jakarta: Ghalia.

Mochammad, M. (1997). Penggunaan Pengadilan Negeri Sebagai Lembaga Untuk Menyelesaikan Sengketa Dalam Masyarakat. (p. 12). Surabaya : Grafika Utama.

Murad, R. (2007). Menyingkap Tabir Masalah Pertanahan. Bandung: Mandar Maju.

Sarjita. (2005). Teknik Dan Strategi Penyelesaian Sengketa Pertanahan Edisi Revisi. Yogyakarta: Pustaka Tugu.

Sitorus, O. (2004). Kapita Selekta Perbandingan Hukum Tanah. Yogyakarta: Mitra Kebijakan Tanah Indonesia.

Sodiki, A. (2009). Politik Hukum Agraria. Yogyakarta: Mahkota Kata.

Soemardjono, M. S. (2017). Pembaruan Agraria-Arti dan Implementasinya. Seminar Nasional Pertanahan-Pembaruan Agraria, (p. 4). Yogyakarta.

Soemitro, R. H. (1997). Metodologi Penelitian Hukum dan Jurimetri . Jakarta: Ghalia.

Supriyadi, B. E. (2013). Hukum Agraria Kehutanan. Jakarta: Grafindo Pustaka.

Sutiyoso, B. (2006). Penyelesaian Sengketa. yogyakarta: citra media.

\section{ARTIKEL JURNAL DAN KARYA ILMIAH :}

Safitri, M. (2011). Menuju Kepastian dan Keadilan Tenurial. Kelompok Masyarakat Sipil Untuk Reformasi Tenurial, 15.

Nurjaya, I. N. (2017). Menuju Pengelolaan Sumber Daya Hutan yang Berorientasi pada Pola Kooperatif, Perspektif Legal Formal. Workshop Peningkatan Fungsi dan Manfaat Sumber Daya Hutan untuk Pengembangan Perusahaan dan Kesejahteraan Masyarakat.

Wulan, Y. C. (2014). Analisa Konflik Sektor Kehutanan di Indonesia 1997-2003. Center for International Forestry Research, 17.

\section{UNDANG-UNDANG DAN PERATURAN :}

Undang-Undang Dasar NRI 1945 
Peraturan Kepala Badan Pertanahan Nasional Nomor 3 Tahun 2011 Tentang Pengelolaan Pengkajian dan Penanganan Kasus Pertanahan

Peraturan Presiden Republik Indonesia Nomor 88 Tahun 2017 Tentang Penyelesaian Penguasaan Tanah dalam Kawasan Hutan

Undang-Undang Nomor 5 Tahun 1960 Tentang Peraturan Dasar Pokok-pokok Agraria

Undang-Undang Nomor 23 Tahun 1997 Tentang Lingkungan Hidup

Undang-Undang Nomor 41 Tahun 1999 Tentang Kehutanan.

Peraturan Menteri Lingkungan Hidup dan Kawasan Hutan Nomor P.97/MENLHK/SETJEN/KUM.1/11/2018 Tentang Tata Cara Pelepasan Kawasan Hutan yang Dapat Dikonversi.

\section{SUMBER ONLINE :}

Roqhmad, A. (2017). Petani vs Negara Studi Tentang Konflik Tanah Hutan Negara dan Resolusinya Dalam Perspektif Fiqh. Retrieved from http://dualmode.kemenag.go.id/acis10/file/dokumen/d2.AbuRokhmad.pdf 